\title{
Comparative characteristics of some ecosystems of the upper regions of the shelf in tropical, temperate and Arctic waters
}

\author{
A. N. Golikov \& O. A. Scarlato \\ Zoological Institute, Academy of Sciences of the USSR; \\ Leningrad, USSR
}

KURZFASSUNG: Vergleichende Charakterisierungen einiger Okosysteme der oberen Schelfregionen in tropischen, gemäßigten und arktischen Gewässern. Die Verteilung der Biozönosen in den oberen Schelfzonen des westlichen Pazifik, der boralen Regionen des Atlantik und arktischer Gewässer wurde unter vergleichenden Gesichtspunkten mit Hilfe der Methode des Schwimmtauchens untersucht. In kalten und gemäßigten Zonen der nördlichen Hemisphäre spielen stets verwandte Arten eine dominierende Rolle in den in ähnlicher Tiefe und auf ähnlichem Substrat lebenden Lebensgemeinschaften. Sie erweisen sich teilweise aud als konvergent gegenüber tropischen Biozönosen, doch stehen deren Charakterarten in keinem näheren Verwandtschaftsverhältnis zu jenen der in der nördlichen Hemisphäre vorkommenden Biozönosen. Die Biomasseproduktion am Boden steigt in Richtung von arktischen $\mathrm{zu}$ tropischen Regionen an; die Populationsdichte der Organismen ist in den gemäßigten Breiten am größten und verringert sich in etwa gleicher Weise zu den tropischen und arktischen Zonen hin. Das Verhältnis der Artenzahl zur Populationsdichte pro Flächeneinheit erreicht in tropischen und arktischen Lebensgemeinschaften ein Maximum; es verringert sich beträchtlich in gemäßigten Breiten. Die geographische Verbreitung der Biozönosen in gleichen Wassertiefen wird in tropischen Gebieten in erster Linie von Strömungen, in borealen Zonen von den Temperaturverhältnissen des Oberflächenwassers und in arktischen Regionen von der Eisbedeckung bestimmt. In tropischen und gemäßigten Zonen findet sich die größte Mannigfaltigkeit an Organismen und die höchste Biomasseproduktion in 0-10 m Wassertiefe, in arktischen Meeren dagegen in einer Tiefe von ca. $18-25 \mathrm{~m}$. In allen untersuchten Gebieten wird eine vertikale Zonierung der Biozönosen deutlich, die im tropischen Bereich vom Lichteinfall und von den hydrodynamischen Besonderheiten der oberen Wasserschichten abhängen, in borealen Zonen von den Oberflächentemperaturen und in den arktischen Gewässern von dem Grad des Lichteinfalls und der Eisbedeckung.

\section{INTRODUCTION}

Within the system of vertical zones in the sea, the upper regions of the shelf are biologically the richest and the most productive.

The study of the structure of biocoenoses, as well as of the quantitative composition and qualitative distribution of organisms constituting the biocoenoses, is of vital importance for the comprehension of processes taking place in their ecosystems, and for proper utilization of economically significant species in the future. 
The comparative ecological analysis of the hydrobiological structure of the populations of the upper parts of the shelves in different landscapes and geographical zones is of particular interest in this respect. This study can suggest both a precise approach to the scientific and industrial utilization of the most significant biocoenoses and offer information on evolution of the supraspecific organization of life in the marine environment.

\section{MATERIAL AND METHOD}

The authors have studied the composition, structure and distribution of life in Possjet Bay in the Sea of Japan (Golikov \& Scarlato 1965, 1967, Scardato et al. 1967), at the coasts of Southern Sakhalin (Golikov 1965, 1966, Golikov \& Scarlato 1968), near the Kuril Islands (Golikov \& Scarlato 1970), in the Chupa Inlet of the White Sea: in Kola Bay, near Novaya Zemlya, in the archipelago of Franz Josef Land (Golikov \& Averunzev 1971), and at the coasts of a number of tropical islands in the western part of the Pacific Ocean (Golikov et al. 1972).

Only after the diving technique had been introduced as a method of scientific research did a comparative quantitative study on life on firm grounds and in a complicated relief of the bottom of the upper parts of the shelf become possible.

All the investigations in coastal areas have been conducted by employing the quantitative diving method (Scarlato et al. 1964, Golmov \& Scarlato 1965) and carried out by the same investigators; hence the results obtained can be compared with each other.

The investigators have explored a region ranging from the supralittoral to a depth of 30 to $40 \mathrm{~m}$. After a preliminary survey of the sea bottom and the local biocoenoses, the diver investigator determined within each biocoenosis over a large area $\left(50-100 \mathrm{~m}^{2}\right)$ the degree of uniformity in the distribution of its leading components. He then measured the areas, peculiar by their correlation of species, and conducted a quantitative collection of the rarest species with the largest individuals and determined their numbers. Then, in different parts of the biocoenoses, collections from areas of $1 \mathrm{~m}^{2}$ to $0.05 \mathrm{~m}^{2}$ were taken according to size, distribution and density of the populations. Samples of each size were made two or three times in each case. The meiobenthic organisms were counted after repeated collections, obtained from areas of $20 \mathrm{~mm}^{2}$. Organisms of the biocoenosis inhabiting the phytal, epifauna and infauna (or endolithofauna) were counted separately.

For this purpose, and for catching mobile organisms of the nektobenthos, special equipment was used (Scarlato et al. 1964, Golikov \& Scarlato 1965). It is usually easy to define the borders of biocoenoses due to their belt distribution at definite depths and grounds and to the presence of background-forming species, characterizing the ecology and energetic peculiarity of biocoenoses (Golkov \& SCARLato 1971).

As the structure of biocoenoses is determined by a regular, almost logarithmic sequence in the arrangement of species according to their biomass, metabolic activity and productivity - whereby one, two or a few species have a decidedly dominant position compared to the rest - corrections regarding the borders between adjacent 
biocoenoses were made (after the material collected had been quantitatively estimated) based on changes in the dominant species. Aboard ship or in mobile field laboratories on the shore, the material collected was classified and divided according to species and wet weight, and the number of specimens of each species was determined.

Later, taxonomic specialists defined the species more precisely; their biogeographical origin was ascertained, their biomass and the population density per $1 \mathrm{~m}^{2}$ was estimated.

In each case the biomass was determined on the basis of wet weight and skeleton material in living specimens. Such procedure best takes into account the conditions in situ. Thereafter, the material was fixed (e. g., in $70 \%$ alcohol, $5 \%$ formalin) for further taxonomical and morphological investigations.

The data collected represent a basis from which to assess the diversity of species peculiar to each region investigated and to establish the population density and total biomass of different biocoenoses. The data also permit the estimation of the productivity of the ecosystem.

In all calculations presented in this paper, macrobenthic organisms only are taken into account; each animal colony (corals, synascidians, bryozoans, etc.) is considered as one individual organism.

\section{RESULTS AND DISCUSSION}

In all the areas investigated, the structure of biocoenoses and the degree of domination of the leading species were identical (Fig. 1). This fact indicates a regular, stable character of the organization of biocoenoses. Figure $1(a, c)$ demonstrates that maximum prevalence of dominant species occurs in littoral biocoenoses. Here, physical and chemical factors, restricting the existence of many species, are exceedingly important. The dominant species also form, as a rule, the essential background. The biomass of the dominant species is usually not only the most important in terms of their energy resources; they also characterize the biocoenosis itself, forming additional ecological niches, and giving shelter and nourishment to many other species (GoLIKov \& SCARLATO 1967).

In the regions investigated, on similar ground the biocoenoses form parallel rows, depending upon the sequence of their vertical distribution (see Figs 2, 3, 4 and 5). Thus, biocoenoses with dominant molluscs of the genus Littorina and cirripedes of the genera Chtbamalus and Balanus are characteristic of the upper horizon of the littoral on stony grounds in temperate waters of the Northern hemisphere.

In temperate waters of the Pacific Ocean off the Asian coasts from South to North, the dominant forms of these biocoenoses follow the sequence: Littorina brevicula + Chtbamalus dalli $\rightarrow$ L. kurila + C. dalliz; while in the Barents Sea and the White Sea, L. saxatilis + Balanus balanoides are the dominant forms.

In temperate and cold waters of the Northern hemisphere, in the upper sublittoral, domination in parallel biocoenoses of related species of seaweeds and other aquatic plants, of gastropods (genera Epheria, Lacuna and Margarites) and amphipods is most characteristic. Thus the biocoenosis Laminaria japonica + Epheria turrita, 
common in low-boreal Asian waters, is substituted by the biocoenoses Laminaria saccharina + Lithothamnion sp. + Epheria vincta, and in the Arctic waters, by L. saccharina + Epberia crassior.

At depths of 10 to $15 \mathrm{~m}$, on firm grounds, the biocoenoses of bivalve molluscs of the family Mytilidae and sea urchins of the genus Strongylocentrotus, which in cold

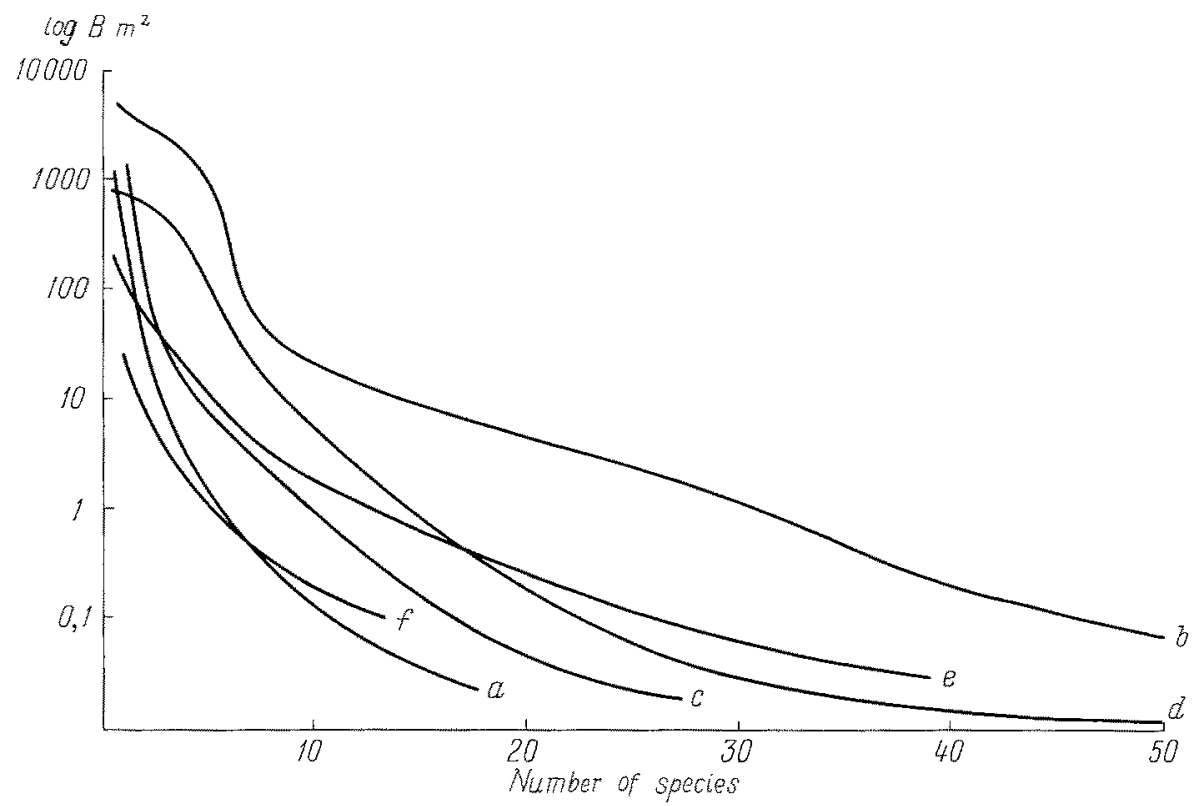

Fig. 1: Distribution of species by biomass in biocoenoses from different zones of the Ocean. a: Biocoenosis Letterstedtia sp. + Clypeomorus sp. (middle horizon of stony littoral), in the neighbourhood of Singapore. b: Biocoenosis Pacillopora sp. + Millipora sp. + Acropora sp. + Porites sp. + Diadema sp. (2-4 m depth, corallogenesis stone), near Nauru Island. c: Biocoenosis Littorina squalida + Chtbamalus dalli (middle horizon of stony littoral), in the open gulf of Possjet Bay (USSR). d: Biocoenosis Scytosiphon lomentaria + Punctaria latifolia + Coccophora langsdorfii + Strongylocentrotus nudus (2-4 m depth, rocks), in the open part of the Possjet Bay. e: Biocoenosis Astarte crenata (20-25 m depth, mud with shells), near Rudolph Island (Franz Joseph Land, USSR). $\mathrm{f}$ : Biocoenosis Ampherusa glacialis (lower surface of permanent ice), near Rudolph Island (Franz Joseph Land). Log Bm²: logarithm of biomass $\left(\mathrm{g} / \mathrm{m}^{2}\right)$. Abscissa: number of species of a given biocoenosis

and temperate waters of the Northern hemisphere compose parallel biocoenoses in different combinations, are common. At greater depths $(20-40 \mathrm{~m})$ and on silted grounds, parallel biocoenoses with bivalve moluscs of the genera Macoma or Astarte predominating can often be observed.

The data obtained conform to the conception of parallelism in the distribution of communities (THorson 1960). Parallelism in the distribution of biocoenoses in the bionomically analogous regions explored is caused, apparently, by identical morphofunctional adaptations of related species and genera to the type of substratum and to hydrodynamic factors. Under favourable conditions, the species and genera mentioned 
develop most abundantly and, consequently, take the leading position in the biocoenoses.

The similarity between tropical and boreal biocoenoses, dwelling at similar depths and on similar grounds, in many cases may be classified as convergency (Fig. 6). For instance, molluscs belonging to the unrelated genera Nerita and Littorina play a

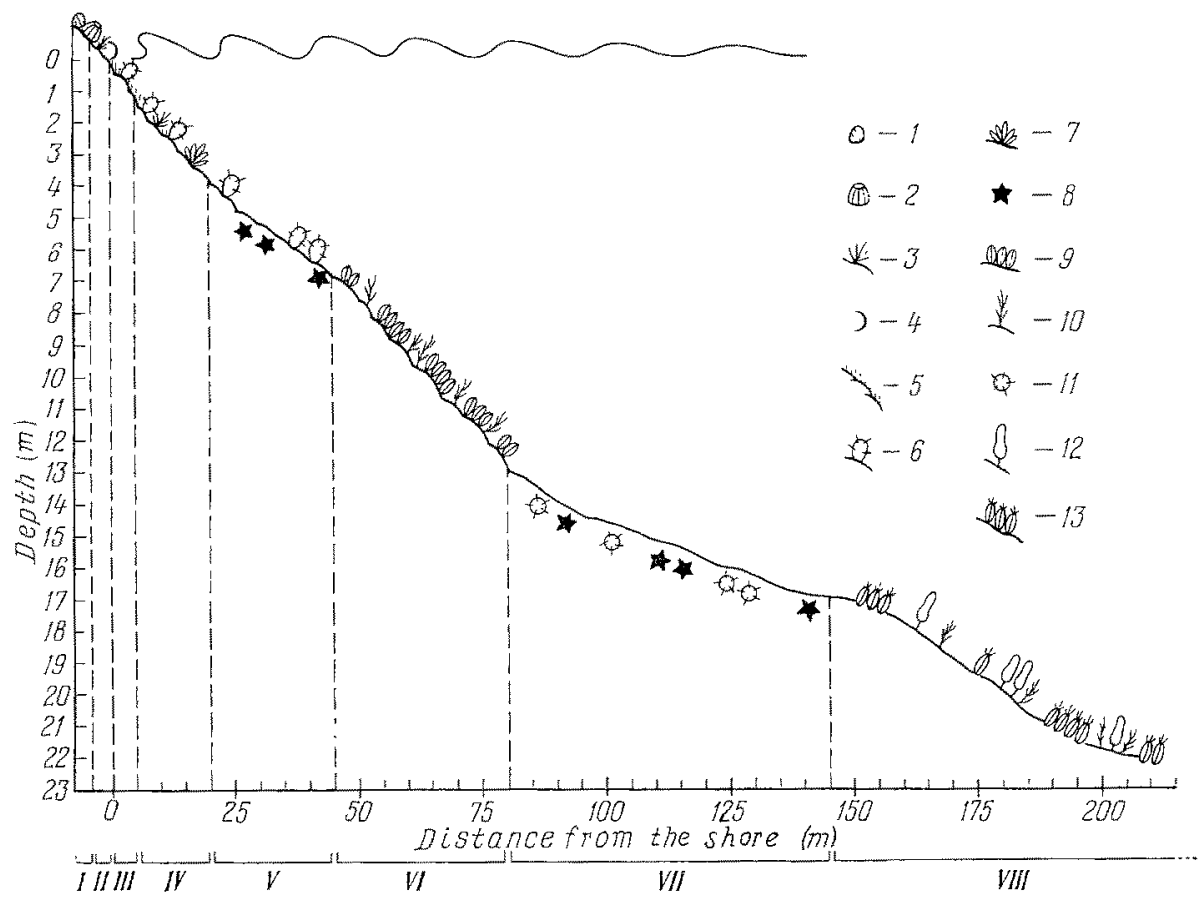

Fig. 2: Vertical distribution of bottom biocoenoses off the open rodky coasts of Possjet Bay (USSR). I: Biocoenosis Littorina brevicula (1) + Chthamalus dalli (2) (supralittoral and upper horizon of littoral, rocks and stones). II: Biocoenosis Gratelupia divaricata, Sphaerotrichia dissessa, Laurencia papillosa (3) + Caprella kristibrachium (4) (middle and lower horizon of littoral, rocks). III: Biocoenosis Pbyllospadix ireatensis (5) + Strongylocentrotus nudus (6) (sublittoral, 0-1.5 m depth, rock, stones). IV: Biocoenosis Scytosiphon lomentaria, Punctaria latifolia, Coccophora langsdorfii (7) + Strongylocentrotus nudus (6) (1.5-4 m depth, rock with stones and gravel in cradks). V: Biocoenosis Patiria pectinifera (8) + Strongylocentrotus nudus (6) (4-7 m depth, rodk). VI: Biocoenosis Crenomytilus grayanus (9) + Desmarestia viridis (10) (7-13 m depth, rock with stones and pebble). VII: Biocoenosis Patiria pectinifera (8) + Ecbinocardium cordatum (11) (13-17 m depth, muddy sand). VIII: Biocoenosis Laminaria cicborioides (12), Desmarestia viridis (10) + Modiolus difficilis (13) (17-21 m depth, sandy mud with shells). (After Golikov \& Scartato 1967)

similar role in littoral biocoenoses, peculiar to firm grounds, the former in the tropical zone and the latter in the temperate zone.

The role which corals and the zooxanthellae associated with them play in tropical waters can be compared with the part played by the sea macrophytes in cold and temperate latitudes; this fact illustrates ecological convergency on a large scale. Seaweeds (algae and marine grasses) in cold and temperate waters, and the reef-forming 
corals in tropical seas, take the leading part in many biocoenoses on firm facias in the shoals, thus giving shelter and food to many other organisms; they often exhibit similar characteristics of domination. The leading role in these biocoenoses is often performed not just by one or two, but by several species (Fig. 1b,1d), composing a single life form and ecological function. Ecologically, seaweeds and reef-forming

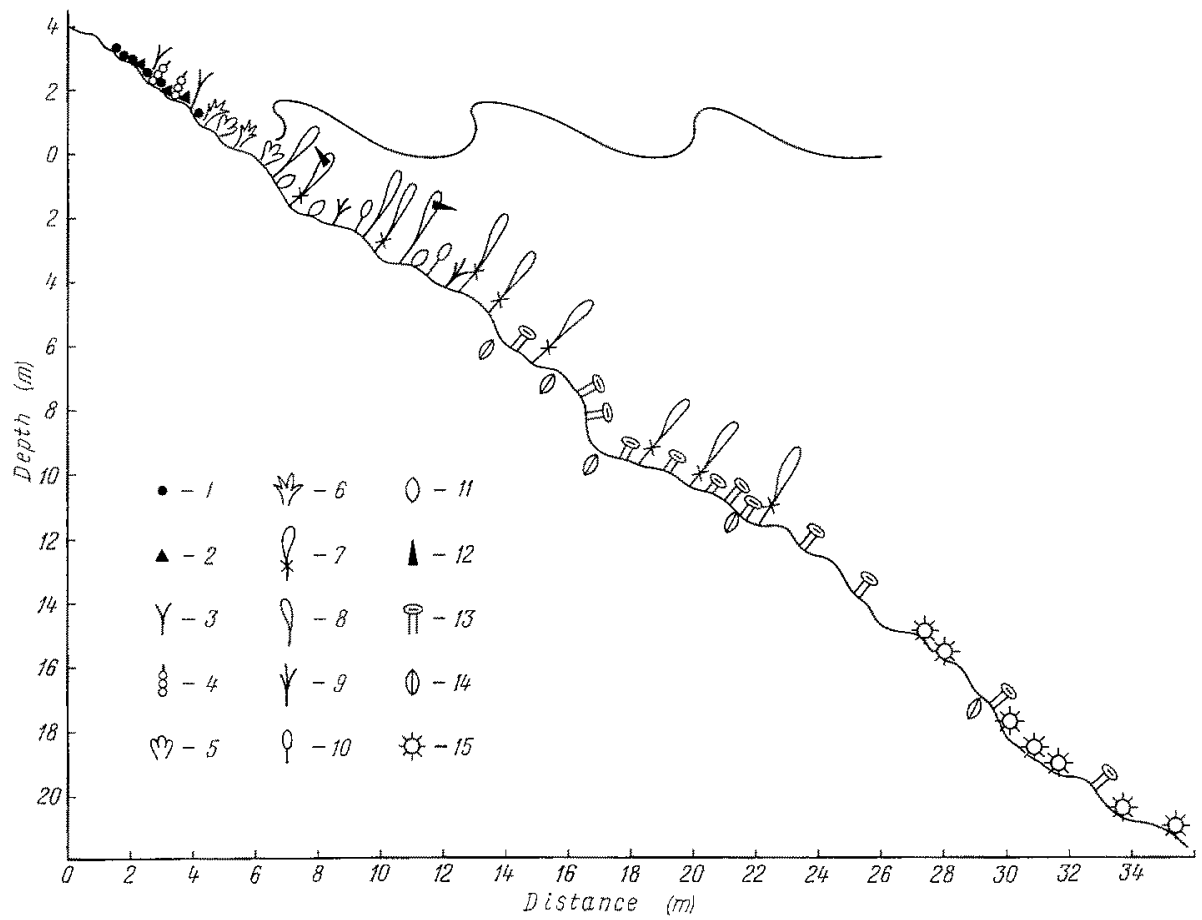

Fig. 3: Vertical distribution of bottom biocoenoses on stony and muddy ground in the inner part of Kola Bay (USSR). I: Biocoenosis Littorina saxatilis (1) + Balanus balanoides (2) (supralittoral and upper horizon of littoral, stones). II: Biocoenosis Fucus vesiculosus (3) + Ascopbyllum nodosum (4) (middle horizon of littoral, stones). III: Biocoenosis Rbodimenia palmata (5) + Fucus serratus (6) (lower horizon of littoral, stones). IV: Biocoenosis Alaria esculenta (7) + Laminaria sacharina (8) + Desmarestia viridis (9) + Rhycodris sinuosa (10) + Polydora sp. (11) + Epheria vincta (12) $(0.5-3.5 \mathrm{~m}$ depth, stones and muddy sands). V. Biocoenosis Metridium senile (13) + Alaria esculenta (7) + Macoma baltica (14) (3.5-14 m depth, sandy mud with stones). VI: Biocoenosis Strongylocentrotus droebacbiensis (15) + Metridium senile (13) (14-20 m depth, sandy mud with stones)

corals can substitute one another. In regions with well-developed coral reefs, therefore, macrophytes are insignificant; in contrast, in biocoenoses with abundant seaweeds, corals are few or absent. In high Arctic latitudes, covered with permanent pack ice, the role of seaweeds in the ecosystems of the upper regions of the shelf is often performed by actinians and alcyonarians of the genus Eunephthya.

To all appearances, only the tropical ecosystems of the mangroves, enjoying a large biomass and a peculiar set of specific species, and the population of the lower 
surface of the pack ice in the Artic and Antarctic Oceans have no analogies in other latitudes.

Organisms inhabiting the lower surface of the ice cover form specific cryopelagic ${ }^{1}$ biocoenoses, represented by small weeds, amphipods, isopods, and the so-called Polar cod-fish Boreogadus saida in the high latitudes of the Artic Ocean. Thus near Rudolph Island (Franz Josef Land), for instance, in the cryopelagic biocoenosis composed of 12 species in autumn and having a total biomass of $36 \mathrm{~g} / \mathrm{m}^{2}$, the value for the leading species Apherusa glacialis (Amphipoda, Caliopiidae) is $24 \mathrm{~g} / \mathrm{m}^{2}$.

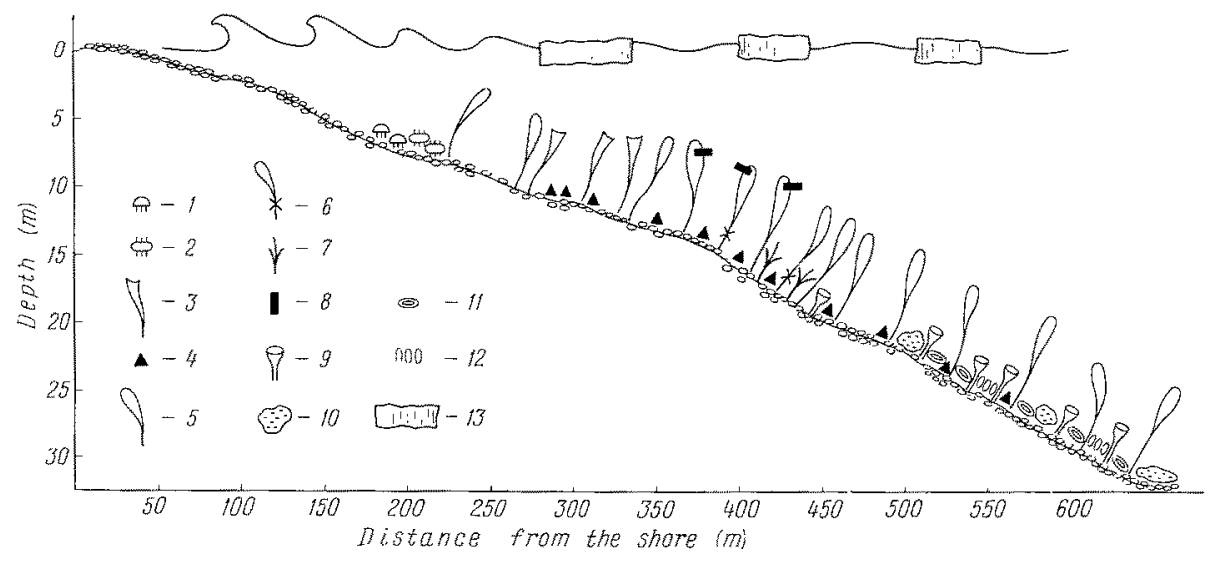

Fig. 4: Vertical distribution of biocoenoses on gravel and sandy grounds near Victoria Island (Franz Joseph Land, USSR). I: Biocoenosis Gammarus setosus (1) + Antinoella sarsii (2) (1.5-10 m depth, pebble, sands). II: Biocoenosis Phyllaria dermatodea (3) + Balanus balanus (4) (10-15 m depth, pebble with sand). III: Biocoenosis Laminaria saccharina (5) + Alaria esculenta (6) + Desmarestia aculeata (7) + Balanus balanus (4) + Epheria crassior (8) (15-23 m depth, pebble and sand). IV: Biocoenosis Phakellia bowerbankii (9) + Synascidia sp. (10) + Alcyonidium distiformis (11) + Musculus corrugatus (12) (23-20 m depth, gravel, stones, muddy sand)

In the lacunas of the soldering ice in the littoral near the Northern islands of the same archipelago peculiar biocoenoses were discovered, in which Gammarus setosus predominated. Such biocoenoses were termed cryolittoral biocoenoses by Gourkov \& Averinzev (1971).

Within the tropical insular shelves examined in the western part of the Pacific Ocean (Golikov et al. 1972), the maximum biomass, consisting mainly of abundant reef-forming madrepore corals, can be observed near New Guinea, which is not wholely isolated from the shelf of the ancient continent, while the minimum biomass can be observed in the remotest, geologically relatively young atolls, e. g., near the Gilbert Islands (Fig. 7a, c).

This phenomenon is caused apparently by the arrival in the region of New Guinea of a larger quantity of larvae of diverse species from geologically more ancient regions

1 The term "cryopelagic" was coined by AnDruaschev (1966) to denote organisms inhabiting the lower surface of the ice in the Antarctic Ocean. 
possessing a diverse and more abundant population compared to that of the archipelagos farther to the East. In addition, the role of the macrophytes in the biocoenoses increases with the decrease in the quantity of corals possessing a smaller potential for wide distribution because of their plankton phase and their specific requirements for further development.

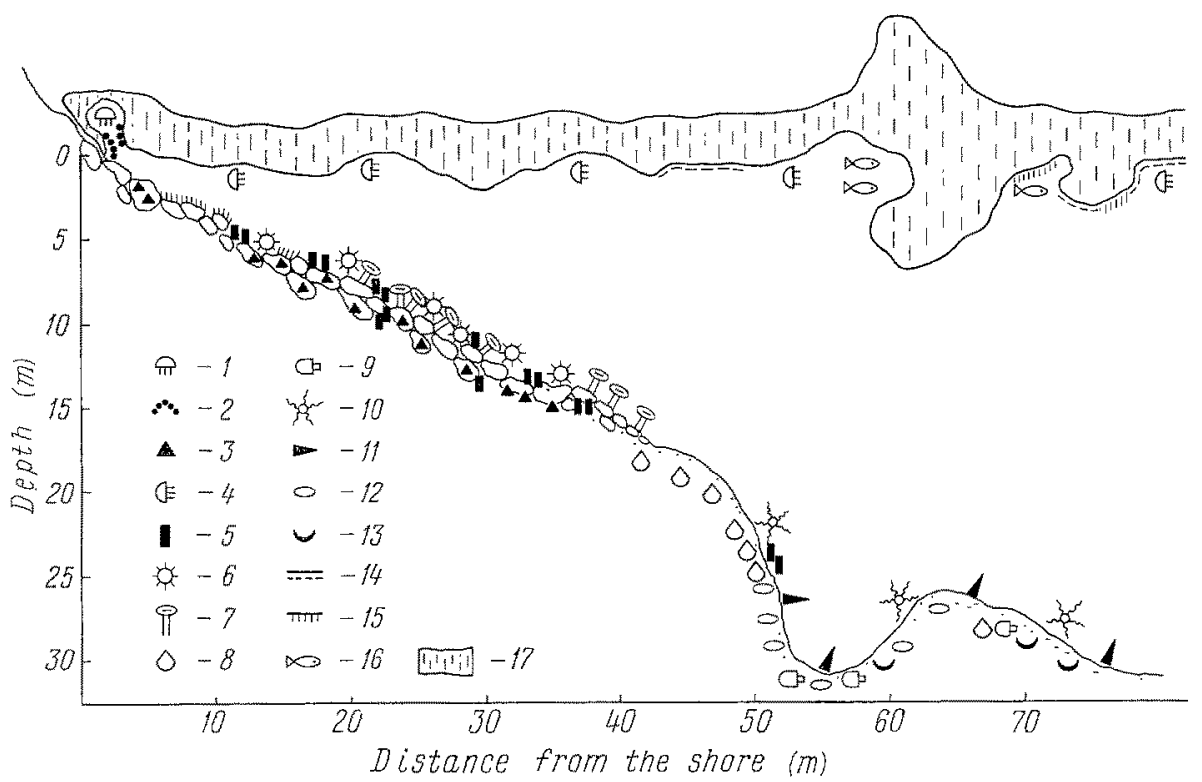

Fig. 5: Vertical distribution of biocoenoses on stony and muddy grounds under ice near Rudolph Island (Franz Joseph Land, USSR). I. Cryolittoral biocoenosis Gammarus seterus (1) + Diatomea g. sp. (2) (lower horizon of littoral in alveole of ice). II: Biocoenosis Balanus balanus (3) + Gammaroidea g. sp. (4) (0.3 m depth, boulders). III: Biocoenosis Balanus balanus (3) + Hiatella arctica (5) + Strongylocentrotus sp. (6). Typical form: Hondractiniidae g. sp. (7) (8-13 m depth, stones). IV: Biocoenosis Astarte crenata (8) + Mya truncata (9); typical forms: Ophiocantba bidentata (10), Neptunea ventricosa (11), Macoma moesta (12), Yoldia byperborea (13) (18-28 m depth, mud with shells). V: Cryopelagic biocoenosis Apherusa glacialis (14); typical forms: Acrosiphonia sonderi (15), Boreogadus saida (16) (on lower surface of pack ice [17])

In temperate latitudes, the average biomass per unit bottom-surface area proves mostly to be smaller than in tropical biocoenoses at similar depths and on similar grounds. This is due mainly to a less developed lime skeleton, while the leading role in many biocoenoses is performed by macrophytes (Fig. $7 \mathrm{~d}$, e). In high latitudes, the average biomass per unit bottom-surface area at depths ranging from 0 to $30 \mathrm{~m}$ diminishes; this can be explained mainly by a striking decrease in seaweed growth (Fig. 7f, g).

The main factors restricting the development of life in the upper regions of the shelf in high latitudes are the following: (1) The small quantity of light received, (2) the mechanic influence of ice, especially of icebergs, which can tear away and destroy the benthic organisms. A converse relationship exists between the development 
of macrophytes and the existence of a permanent ice cover. In the upper regions of the shelf, which are covered by permanent ice throughout the year, almost no macrophytes occur, while under the lower ice surface cryopelagic biocoenoses develop. In parts

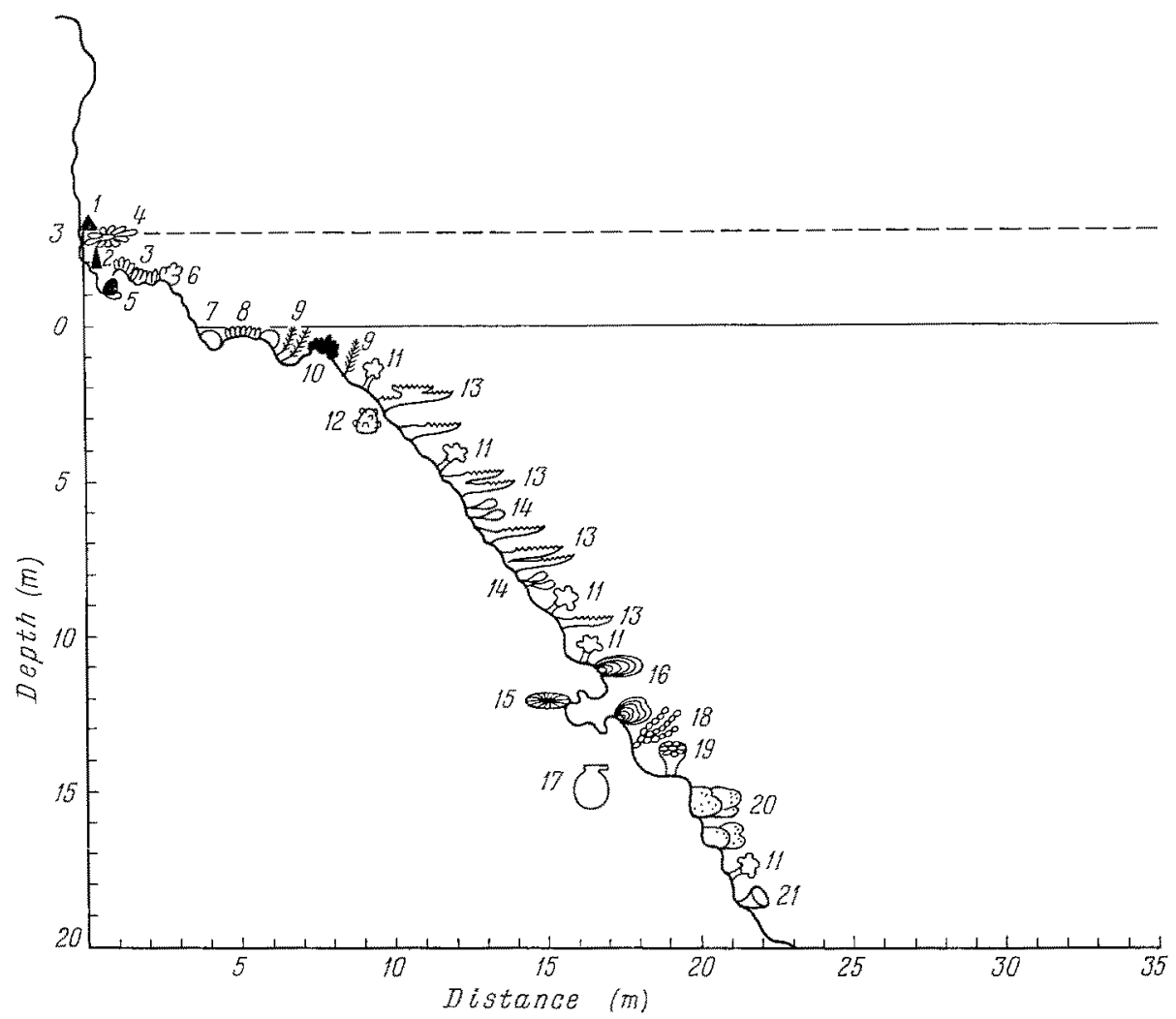

Fig. 6: Vertical distribution of bottom biocoenoses on corallogenes rodks in Constantine Bay (New Guinea). I: Biocoenosis Nerita sp. (1) + Thais sp. (2) (upper horizon of littoral, on coralline limestone). II: Biocoenosis Platigyra sp. (3); typical forms: Protocentrotus sp. (4), Pagurus sp. (5), Spongia g. sp. 1 (6) (lower horizon of littoral, plate of dead corals). III: Biocoenosis Favites sp. (7) + Acropora gupii (8); typical forms: Lithocarpus sp. (9), Spongia g. sp. 2 (10), Alcyonaria g. sp. (11), Vasum ceramicum (12) $(0-3 \mathrm{~m}$ depth, plate of dead corals). IV: Biocoenosis Acropora prostrata (13); typical form: Spongia g. sp. 3 (14) (3-12 m depth, fragments of corals and coarse-grained sand). V: Biocoenosis Fungia sp. (15) + Pacbiseris sp. (16); typical forms: Pteria sp. (17), Halimeda sp. (18), Caryophyllia clausi (19) (12-15 m depth, fragments of corals and coarse-grained sand). VI: Biocoenosis Leptoseris sp. (20) + Spongia g. sp. 4 (21) (15-20 m depth, fragments of corals, sand and mud)

which have been free from ice cover even for only a short period, however, there are seaweeds on the ground in summer, but no cryopelagic biocoenoses (Figs. 4, 5).

The average population density of bottom organisms per $1 \mathrm{~m}^{2}$ attains a maximum in temperate waters, and decreases in the upper regions of the shelf in the tropics and in the Arctic Ocean (Fig. 8). This is subject to change, however, and depends on the spawning period index; in tropical ecosystems, this index is not large due to the large 


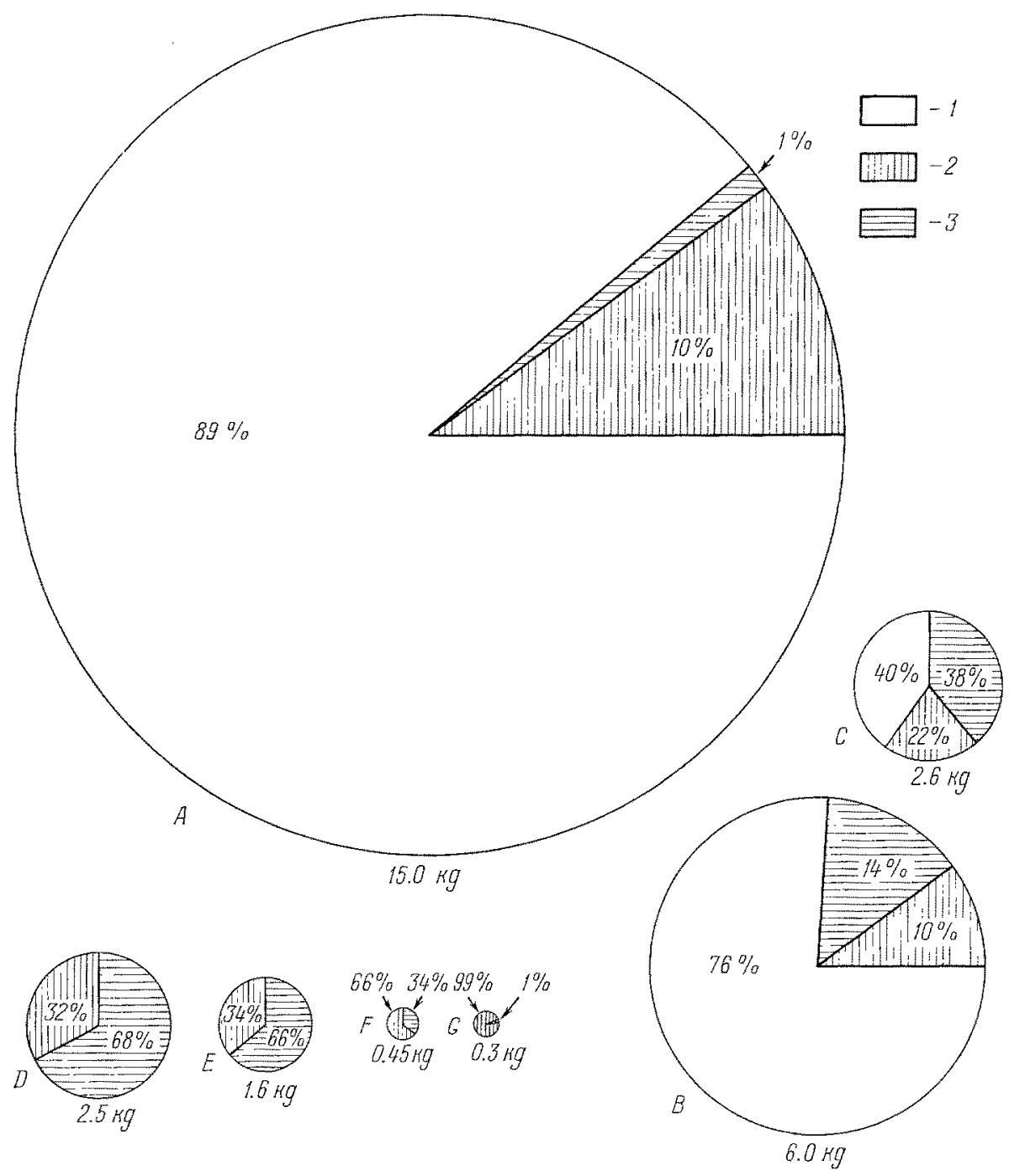

Fig. 7: Correlation of biomass of macrophytes of madreporal corals and other animals in biocoenoses of different zones of the Ocean. Areas of diagrams are proportional to mean biomass of benthos calculated per $\mathrm{m}^{2}$ of bottom surface at depths ranging from upper horizon of littoral to $25-30 \mathrm{~m}$. A: Constantine Bay (New Guinea); B: Near Nauru Island; C: Near atolls Butaritari and Marakei (Gilbert Islands); D: Open part of the Possjet Bay (Sea of Japan); E: Inner part of Kola Bay (Barents Sea); F: Near Victoria Island (Franz Joseph Land); G: Near Rudolph Island (Franz Joseph Land). 1: Madreporous coralls; 2: Other animals; 3: Macrophytes

size of individuals of the leading species; in arctic ecosystems, however, it is small, due to the insignificant quantity of small-sized individuals of a few phytal species. The quantity of species per $1 \mathrm{~m}^{2}$ is usually maximum in temperate waters, but comparatively small in tropical and in arctic ecosystems. 


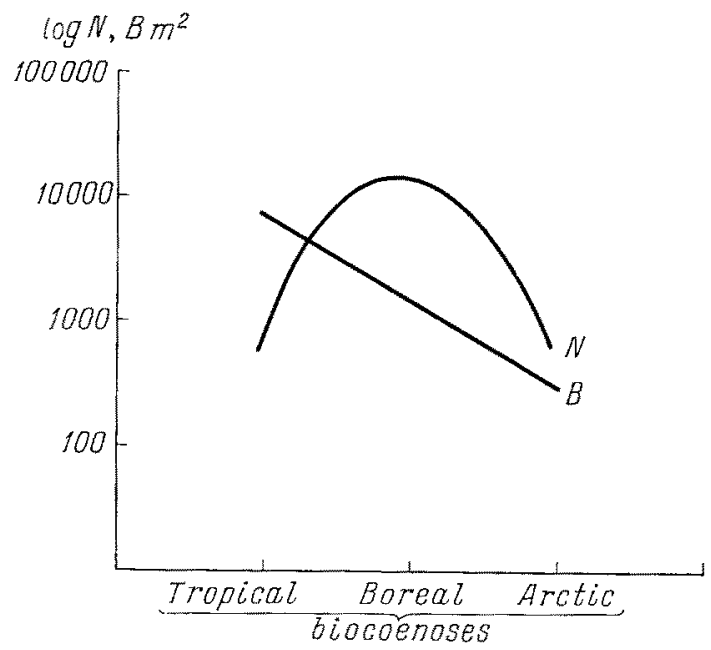

Fig. 8: Dependence of mean population density $(\mathrm{N})$ and biomass $(\mathrm{B})$ per $\mathrm{m}^{2}$ in different zones

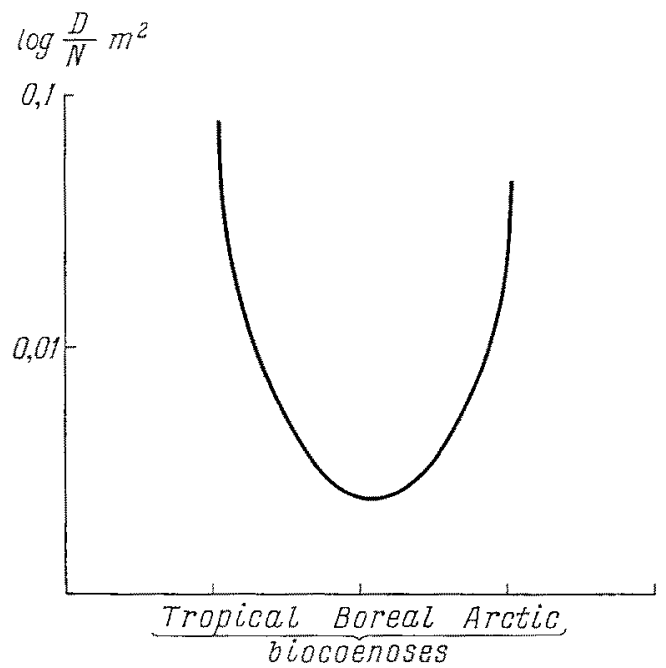

Fig. 9: Dependence of mean ratio of species diversity (D) and population density (N) per $\mathrm{m}^{2}$ of bottom surface. The number of species is divided by the number of individuals (average values $/ \mathrm{m}^{2}$ )

However, due to pronounced differences between the species composing neighbouring biocoenoses in tropical waters, the number of species, when summed up, increases with the increase of the surface area investigated by far more than in arctic and temperate waters which entertain more uniform populations. The total diversity of species in tropical ecosystems is far greater than in other regions of the World Ocean. The ratio of the quantity of species per $1 \mathrm{~m}^{2}$ to the density of populations in the same area proves to be large in tropical and arctic waters, while it is small in 
temperate latitudes, due to the high density of populations of separate species (Fig. 9). The fact that the diversity of species related to the number of individuals is similar in tropical and arctic ecosystems, conforms with the hypothesis that the index discussed depends on the stability of hydrological conditions (SANDERs 1968, 1969). However, due to methodological differences in collection, deviating interpretation of the data obtained, and the fact that all groups of macro-organisms dwelling on different grounds have been included in our study, it would be premature to compare in detail the results of our investigations with those of SANDERS.

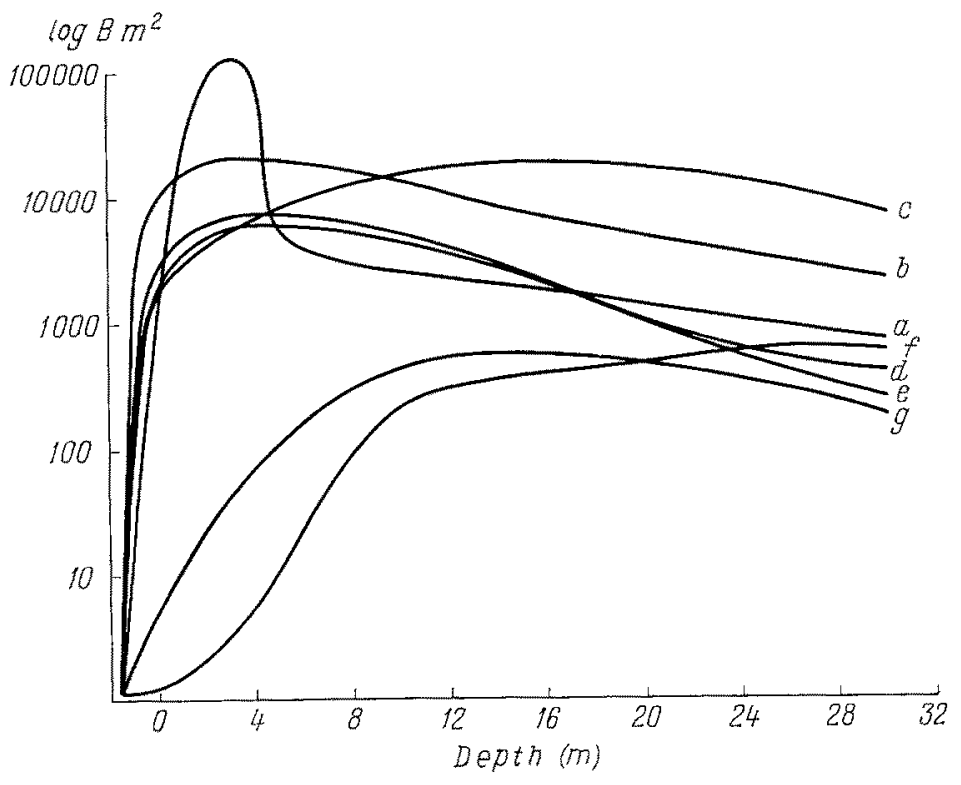

Fig. 10: Dependence of biomass of benthic biocoenosis (B) on depth. Log. biomass (B) per $\mathrm{m}^{2}$. a: Bay of Constantine (New Guinea); b: near Nauru Island; $c$ : near atoll Marakei (Gilbert Island); d: open part of the Possjet Bay (Sea of Japan); e: inner part of the Kola Bay (Barents Sea); f: near Victoria Island (Franz Joseph Land); g: near Rudolph Island (Franz Joseph Land)

The distribution of organisms composing the biocoenoses in the upper shelf regions of tropical latitudes, in the Arctic and in temperate waters depends on different factors. Within tropical waters, with their relatively constant thermal regime, organismic distributions, on similar facias and at similar depths, depend to a large extent on the degree of isolation of different parts of the shelf from the ancient portions of the shelf possessing a diverse and abundant fauna and flora; moreover, distributions depend on the direction of the prevalent water currents and on the hydrodynamic peculiarities of some individual areas of the shoals.

In temperate waters, the environmental factor temperature is of greatest importance. In regions with strong seasonal temperature fluctuations, water temperature depends mainly on the heat exchange between sea and atmosphere (e. g. in Pacific Asian. low boreal waters); in other waters, on force and direction of prevalent currents (e. g. in North Atlantic European waters). Accordingly, in the former regions the flora 
and fauna of the sheltered, well-heated (summertime) bays are characteristic of warmer waters, and differ from the comparatively cold-water fauna and flora near unsheltered coasts; also, populations of unsheltered coasts along the warm Atlantic current are more characteristic of warmer waters than populations of sheltered bays and fjords (Golikov \& SCARLATo 1968).

This fact leads to intrazonations in the biogeographical regions of the upper part of the shelf, manifested, for example, (1) in populations of bays and lagoons, sub-

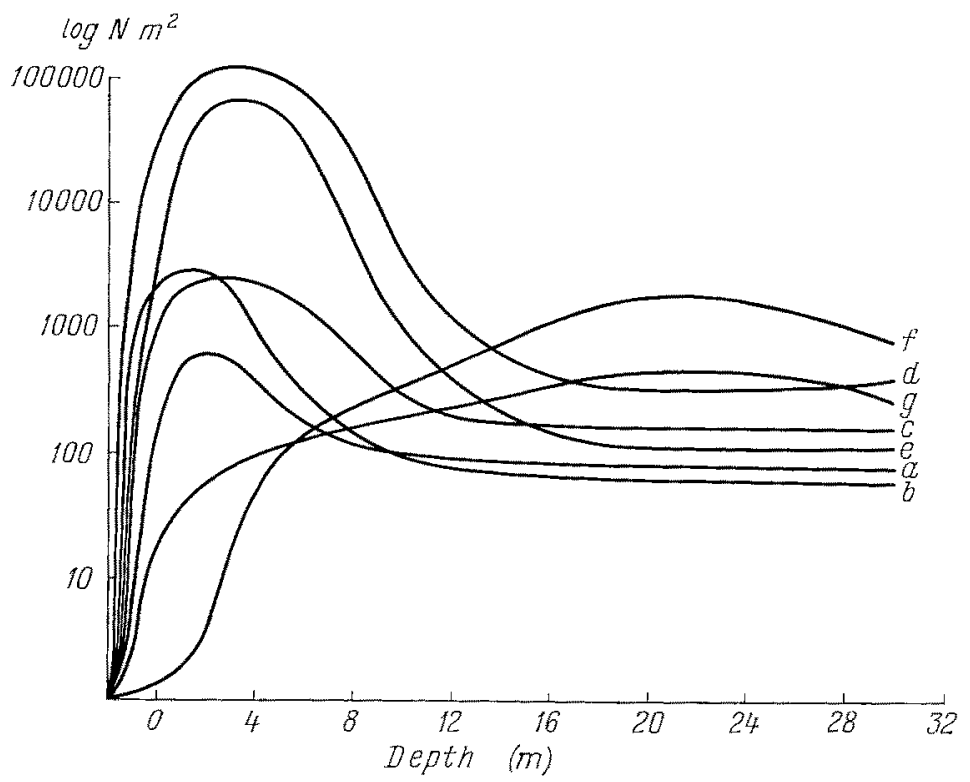

Fig. 11: Dependence of population density $(N)$ within the biocoenosis on depth. Log of number of individuals (N) per $\mathrm{m}^{2}$. Designations of curves are the same as in legend to Figure 10

tropical in origin but inhabiting the Pacific Asian subregion, which on the whole is low boreal (Golxxov \& Scarlato 1967); and (2) in the Arctic populations of the fjords within the borders of the boreal region in the North Atlantic Ocean.

The distribution of organisms in the Arctic Ocean, exhibiting insignificant seasonal changes of temperature in surface waters, depends considerably on ice conditions (a fact already pointed out) and on the quantity and solidity of the icebergs in particular.

In all the regions investigated, a more or less distinct vertical zonation in the distribution of biocoenoses was discovered, which in tropical, temperate and arctic water is caused by different factors. In tropical shoals, the borders between adjacent biocoenoses are less distinct than in other latitudes (apparently due especially to lack of thermal differences in layers of surface-water masses); however, changes in dominant species are clearly recognizable. The maximum biomass can be observed here in the zone of abundant development of reef-forming corals at depths of 0 to $10 \mathrm{~m}$; at depths of 2 to $4 \mathrm{~m}$ it can approach $100 \mathrm{~kg} / \mathrm{m}^{2}$ (Fig. 10a, b, c) mostly due to skeleton formations. Approximately at the same depth range in the tropical part of the 
Pacific Ocean, the highest population density and the greatest species deversity per $1 \mathrm{~m}^{2}$ can be observed in each biocoenosis (Figs. $11 \mathrm{a}, \mathrm{b}, \mathrm{c}, 12 \mathrm{a}, \mathrm{b}, \mathrm{c}$ ).

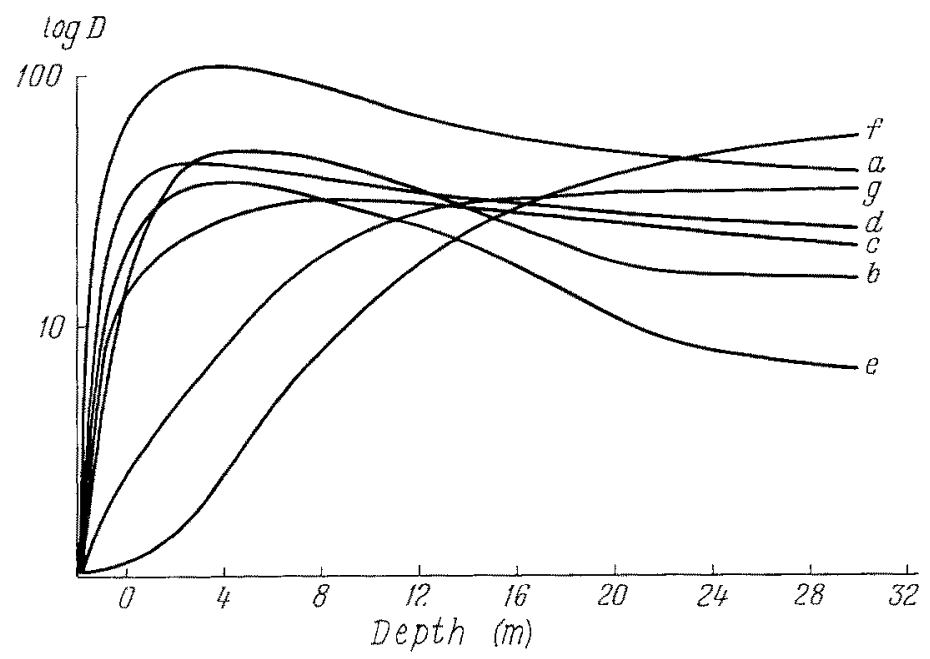

Fig. 12: Dependence of species diversity (D) within the biocoenosis on depth. Log of number of species (D) per $\mathrm{m}^{2}$. Designations of curves as in legend to Figure 10

Zonations in the vertical distribution of biocoenoses in tropical waters over the depth ranges explored depend on the degree of light penetration and on the hydrodynamic peculiarities of different layers of the surface water masses. The environmental factor light exerts its influence mainly through the zooxanthellae which, in turn, affect the vital activities of the corals, while hydrodynamic peculiarities influence the selection of life forms of the corals, differing by the degree of structural ability at different depths.

In temperate waters, maximum abundance and maximum variety of life are observed approximately at the same depths as in tropical waters (Figs. 10d, e, 11d, e, $12 \mathrm{~d}, \mathrm{e})$, but the largest biomasses in this region are affected to a considerable degree by the development of macrophytes. The borders between the biocoenoses, forming separate zones at similar depths and on similar grounds, are more clearly expressed than those in the tropical regions. Zonation in the distribution of temperate biocoenoses as a function of depth in the upper shelf regions on similar grounds is determined in the first place by the temperature regime of the surface waters. The borders between dominant species of the biocoenoses conform with the thermocline in spring and summer, and correspond to the borders between the layers of the surface water masses (Golikov \& Scarlato 1967, 1968).

The maximum biomass, maximum population density and maximum variety of species in the high latitudes of the Arctic Ocean can be observed at the coasts of Franz Josef Land at depths of about 18 to $25 \mathrm{~m}$ (Figs. 10f, g, 11f, g, 12f, g). Such increased development in life at greater depths in the Arctic is apparently due to less mechanical influence of the ice and to the continual existence, at about $20 \mathrm{~m}$, of a 
layer of heated water during summer, insignificant as it is, reaching $-0.3^{\circ}$ to $-0.6^{\circ} \mathrm{C}$ (Golikov \& Averinzev 1971). In addition, formation of pack ice over greater depths, carrying cryopelagic biocoenoses which supply the organic substance necessary for the bottom population, can considerably influence life abundance. Vertical zonation in Arctic waters on similar grounds is caused to a considerable extent by the degree of light penetration and by the character of ice conditions prevalent over different depths.

\section{SUMMARY}

1. The distribution of biocoenoses in the upper shelf parts of temperate and tropical regions in the western part of the Pacific Ocean, in upper boreal Atlantic waters and in the high latitudes near Franz Josef Land has been investigated employing the quantitative diving method.

2. In bionomically analogous parts of temperate and cold waters of the Northern hemisphere, parallelism in the distribution of biocoenoses can be observed. The leading (dominant) forms are substituted by vicarious species. A series of biocoenoses in these waters corresponds to tropical biocoenoses located at similar depths and on similar grounds. Reef-forming corals, dominant in many tropical biocoenoses, are replaced by macrophytes, especially in cold and temperate waters (convergency on a larger scale).

3. The biomass of bottom biocoenoses attains maximum values in tropical waters and decreases regularly towards the high latitudes of the Arctic Ocean.

4. Population density is maximum in biocoenoses of temperate latitudes; it decreases more or less equally in tropical and Arctic waters. The ratio of the quantity of species to population density per $1 \mathrm{~m}^{2}$ of bottom surface area is maximum in tropical and Arctic biocoenoses and diminishes considerably in temperate waters.

5. The geographical distribution of biocoenoses on similar grounds and at equal depths depends (a) in tropical waters upon the direction of prevalent currents and upon the degree of isolation of island shelves from the ancient continental shelf areas with diverse and abundant populations; (b) in temperate waters, upon the temperature regime of the surface waters (heat exchange between sea and atmosphere; influence of the prevalent water currents); (c) in Arctic waters, upon the solidity and constancy of the ice cover.

6. In tropical and temperate waters, maximum biomass, maximum population density and greatest species diversity are observed at depths ranging from 0 to $10 \mathrm{~m}$, in Arctic waters from about 18 to $25 \mathrm{~m}$, due to ice conditions in the shoals which are unfavourable for life.

7. In all areas investigated, the distribution of biocoenoses reveals a distinct vertical zonation. The zonation is caused in tropical waters (on identical grounds), by the degree of light penetration and by hydrodynamic peculiarities of different layers of the surface water mass; in temperate waters by differences in the thermal regime of the layers of the surface water masses; in the Arctic waters by the degree of light penetration, by the mechanical influence of ice, especially of icebergs, and by the mode of ice conditions prevailing over different depths. 
Acknowledgements. We are exceedingly grateful to Professor Dr. O. KINNE, Leading Director and Professor of the Biologische Anstalt Helgoland (FRG), for scientific advice during the preparation of this article.

\section{LITERATURE CITED}

ANDRIAshev, A. P., 1966. About microflora and fauna connected with Antarctic coastal ice. (Russ.) Zool. Zh. 46 (10), 1585-1593.

GoLIKov, A. N., 1965. Comparative ecological analysis of certain marine bottom biocoenoses in South Primorje and South Sakhalin and their exploitation. Problems of hydrobiology. (Russ.) Conf. All-Union Hydrobiol. Soc. 1, 94-95.

- 1966. Ecological peculiarities of coastal marine bottom biocoenoses of South Primorje and South Sakhalin in connection with hydrological conditions. Int. oceanogr. Congr. 2, 136-137.

- \& Averinzev, V. G., 1971. Some regularities in life distribution in the upper regions of the shelf in the archipelago of Franz-Josef Land. Summary report session on the results of investigations in 1970. (Russ.) Zool. Inst. Acad. of Science, Izd. Nauica, 11-12.

- \& Scarlato, O. A., 1965. Hydrobiological explorations in the Possjet Bay by means of the SCUBA diving technique. (Russ.) Issled. Fauny Morei 3 (11), 5-19.

- - 1967. Ecology of bottom biocoenoses in the Possjet Bay (the Sea of Japan) and the peculiarities of their distribution in connection with physical and chemical conditions of the habitat. Helgoländer wiss. Meeresunters. 15, 193-201.

- 1968. Vertical and horizontal distribution of biocoenoses in the upper zones of the Japan and Okhotsk seas and their dependence on the hydrological system. Sarsia 34, 109-116.

- - 1970. Regularities in the distribution of biocoenoses in the upper region of the shelf in temperate waters depending on the character and structure of the water masses. Biological processes in sea and continental reservoirs. (Russ.) Conf. All-Union Hydrobiol. Soc. 2, 83-84.

- - 1971. Some results of hydrobiological diving investigations of the Possjet Bay (the Sea of Japan). (Russ.) Gidrobiol. Zh. 7 (5), 32-37.

- Naumov, D. V., Krasnov, S. V. \& Moskaley, L. I., 1972. Some regularities in the distribution and structure of biocoenoses in the upper regions of insular shelves in tropical latitudes of the western part of the Pacific Ocean. Summary report session on the results of investigations in 1971. (Russ.) Zool. Inst. Acad. of Science, Izd. Nauica, 10-11.

SANDERS, H. L., 1968. Marine benthic diversity: A comparative study. Am. Nat. 102 (225), 243-282.

- 1969. Benthic marine diversity and the Stability-Time-Hypothesis. Diversity and stability in ecological systems. Brookhaven Symp. Biol. 2, 71-81.

Scarlato, O. A., Golmov, A. N. \& Grusov, E. N., 1964. The SCUBA diving technique for hydrobiological investigations. (Russ.) Okeanologija 4, 707-719.

- - Vasilenko, S. V., Tzvetrova, N. L., Grusov, E. N. \& Nesis, K. N., 1967. Composition, structure and distribution of bottom biocoenoses in the coastal waters of the Possiet Bay, the Sea of Japan. Biocoenoses of the Possjet Bay (the Sea of Japan). (Russ.) Issled. Fauny Morei 5, 5-61.

Thorson, G., 1960. Parallel level-bottom communities, their temperature adaptation and their "balance" between predators and food animals. In: Perspectives in marine biology. Ed. by A. A. Buzzatr-Traverso. Univ. Calif. Press, Berkeley, Calif., 67-86.

First author's address:

Dr. A. N. Golikov

Zoological Institute of the Academy of Sciences

Leningrad V-164

USSR 